\title{
Economic History and Contemporary Challenges to Globalization
}

\author{
Kevin HJortshøj O’Rourke
}

The article surveys three economic history literatures that can speak to contemporary challenges to globalization: the literature on the anti-globalization backlash of the nineteenth century, focused largely on trade and migration; the literature on the Great Depression, focused largely on capital flows, the gold standard, and protectionism; and the literature on trade and warfare.

The growth of world trade slowed sharply after 2011, both in absolute terms and relative to the growth of world output. Rather than growing faster than world gross domestic product (GDP), it only grew at the same speed; indeed, in 2016 it grew less rapidly. ${ }^{1}$ These facts prompted concern on the part of organizations such as the World Trade Organization (WTO) and International Monetary Fund, and led journalists to ask whether we were witnessing the end of globalization. In 2015, for example, the Washington Post suggested that "the phenomenon ... may be coming to an end." ${ }^{2}$ During the following year, journalistic speculation regarding the imminent demise of globalization increased still further, following the U.K.'s Brexit referendum in June and the election of Donald Trump to the U.S. presidency in November. Commentators and politicians have debated the causes of both political upsets, as well as their potential consequences, and now academic economists and political scientists are entering the fray (e.g., Allcott and Gentzkow 2017; Becker, Fetzer, and Novy 2017; Dhingra et al. 2017; Inglehart and Norris 2016). What, if anything, can economic history contribute to the discussion?

During the 1990s, as the integration of the international economy was deepening at an accelerating rate, economic historians responded to the commentary of the time by pointing out that globalization was not a

The Journal of Economic History, Vol. 79, No. 2 (June 2019). (C) The Economic History Association. All rights reserved. doi: 10.1017/S0022050719000044. This is an Open Access article, distributed under the terms of the Creative Commons Attribution licence http://creativecommons.org/licenses/by/4.0/), which permits unrestricted re-use, distribution, and reproduction in any medium, provided the original work is properly cited.

Kevin O'Rourke is Chichele Professor of Economic History, All Souls College, Oxford OX1 4AL. E-mail: kevin.orourke@all-souls.ox.ac.uk.

I am very grateful to Dan Bogart, Ann Carlos, Bill Collins, Barry Eichengreen, Simon Evenett, Tim Hatton, Morgan Kelly, Maury Obstfeld, Cormac Ó Gráda, and Jeff Williamson for their many helpful suggestions and comments. The paper was written during a sabbatical year spent in the School of Economics at University College Dublin and I am deeply appreciative of the School's hospitality and practical support. The usual disclaimer applies.

${ }^{1}$ https://www.wto.org/english/news_e/pres17_e/pr791_e.htm

2 "The End of Globalization?" Washington Post, 20 September 2015. 
new phenomenon, as did other scholars such as Paul Hirst and Grahame Thompson (1996). They also argued that it was not irreversible, since it had been reversed in the past. Paul Bairoch (1989) had already written about the protectionist trade policy U-turn experienced in Europe from the late 1870s onwards. At the very end of his Presidential Address to the Economic History Association, Jeffrey Williamson suggested that late nineteenth century globalization might have "seeded its own destruction," by creating losers as well as winners (1996, p. 302). That suggestion was followed up by authors such as Kevin O'Rourke (1997), Ashley Timmer and Williamson (1998), Williamson (1997, 1998), and Timothy Hatton and Williamson (1998), and was one of the main themes of O'Rourke and Williamson (1999). Harold James (2001) continued the story into the interwar period. The events of 2016 may have come as less of a surprise to authors such as these.

But just as economic historians' first instinct was to try to temper some of the "globaloney" of the 1990s (Strange 1998), so their first task today should perhaps be to calm talk of the imminent demise of globalization. Economic history has something to say about what deglobalization looks like, and about whether what we are experiencing today matches that description. Economic historians, and historians more generally, can speak to the issue of whether the causes of Brexit and Trump were economic or not. And finally, economic history has something to say about the political stresses to which globalization may be subjected in the years ahead.

After a brief discussion of what I mean by "globalization" and "deglobalization," and of whether we are already experiencing the latter, I consider three economic history literatures that speak to the state of the world today: the 1990s literature on the anti-globalization backlash of the late nineteenth century, focused in particular on trade and migration; the literature on interwar protectionism; and the literature on the links between trade and warfare.

\section{DEFINING GLOBALIZATION}

Globalization has many facets, several of which are noneconomic (e.g., international criminal justice or the globalization of culture). Economic historians have, not surprisingly, focused on the economic dimensions of the phenomenon. In this essay, therefore, when speaking of "globalization" I primarily mean the integration of international markets for commodities, labor, and capital. By the integration of markets, I mean reductions in the costs of doing business internationally_of moving 
goods, people, or capital between countries or continents. Those costs could fall because of better technology - such as better navigation techniques, the discovery of new ocean routes, the construction of canals, more efficient forms of overland or maritime transport - or because of political factors promoting international economic integration, such as the emergence of geopolitical stability or more liberal domestic trade policies. Technological transfer is another important economic dimension of globalization that is crucial to the long-run dynamics of economic growth. I will occasionally allude to it, as well.

As O'Rourke and Williamson (2002) emphasize, globalization thus defined will be reflected in declining price gaps between markets. Ceteris paribus falling costs will lead to more trade (or migration, or capital flows, as the case may be), which is why it makes sense to look at the size of flows as well as price gaps. It seems reasonable on a priori grounds to expect that price gaps between markets that were closer together fell earlier than price gaps between markets that were further apart, and that ceteris paribus price gaps fell earlier for more valuable commodities than for cheaper and bulkier ones. O'Rourke and Williamson argued, based on the evidence available to them at the time, that intercontinental price gaps only started to fall systematically in the nineteenth century. The claim gave rise to a large literature (for a recent survey see Federico (2018)). We now know that while the volume of trade and the speed of price convergence were indeed much more impressive in the nineteenth century than before, evidence of price convergence can also be found during the early modern period (e.g., Pim de Zwart (2016) on the trade between the Netherlands and Asia). O'Rourke and Williamson (2009) themselves argue that Vasco da Gama played an important role in integrating Eurasian spice markets.

There is, of course, a vast literature on international trade during the early modern, medieval, and even classical periods: long-distance markets may have been characterized by large price gaps, but flows of commodities, and perhaps more importantly of slaves, technology, germs, and specie were sufficient at times to have transformative effects on economies (see inter alia Abu-Lughod 1989; Flynn and Giráldez 2004; Findlay and O'Rourke 2007; Wilson and Bowman 2017). And just as you can find evidence of globalization before the nineteenth century, depending upon your definition, so also can you find evidence of deglobalization, often linked to geopolitical upheaval such as the collapse of the Roman Empire, the end of the pax Mongolica, the disintegration of the Timurid Empire, or political crises in Persia or China (Lopez 1987, pp. 385-89; Rossabi 1990; Ward-Perkins 2005). But as we will see, just 
as the globalization of the nineteenth century and later was different from what had gone before, so were the backlashes produced by it.

\section{HAS GLOBALIZATION ENDED?}

The 1930s remain the canonical example of deglobalization. That decade saw a worldwide increase in tariffs, as well as widespread resort to quotas, exchange controls, multiple exchange rates biased against imports, and a variety of clearing arrangements. Discrimination was rife. In contrast, average tariffs barely rose between 2008 and 2017, although 7.4 percent of world exports were facing higher tariffs in the latter year than in the former (O'Rourke 2018a; personal communication from Simon Evenett). It is true that 2018 saw the introduction of a wide range of tariffs by the U.S. administration, as well as retaliatory measures by several of its trading partners. However, despite this fact, as well as the widespread resort to non-tariff barriers of various kinds and policies artificially promoting exports, documented by the Global Trade Alert database, most economic historians would agree that interwar protection was far more ubiquitous and intrusive than what we have seen since $2008 .{ }^{3}$ Figure 1 shows that as of 2017 U.S. tariffs remained at historically low levels. ${ }^{4}$ At the time of writing (November 2018), it seems entirely possible that Brexit will eventually lead to a serious disintegration of markets linking the United Kingdom and European Union (EU), and the implications of President Trump for U.S. trade policy and the WTO appear increasingly alarming. But to date there has been no return to protectionism in the aftermath of 2008 comparable to what was experienced after 1929.

World trade growth accelerated in 2017. But in any event, using trade volumes alone as evidence of deglobalization is mistaken. These can rise or fall because of underlying shifts in supply or demand, unrelated to the costs of doing business across borders. If those costs do not change, and companies decide to slow or even reverse their outsourcing activities because of changing relative wages, for example, this hardly counts as "deglobalization." That is why, as noted earlier, many economic historians have used price evidence to assess the integration or disintegration of international markets. Comparatively little work has been done on

\footnotetext{
${ }^{3}$ The Global Trade Alert database of state interventions affecting trade since November 2008 is available at http://www.globaltradealert.org.

${ }^{4}$ These are weighted average tariffs, and are thus subject to the criticisms outlined in Anderson and Neary (2005). But few would dispute that Figure 1 gives an accurate indication of long-run trends in U.S. average tariffs.
} 


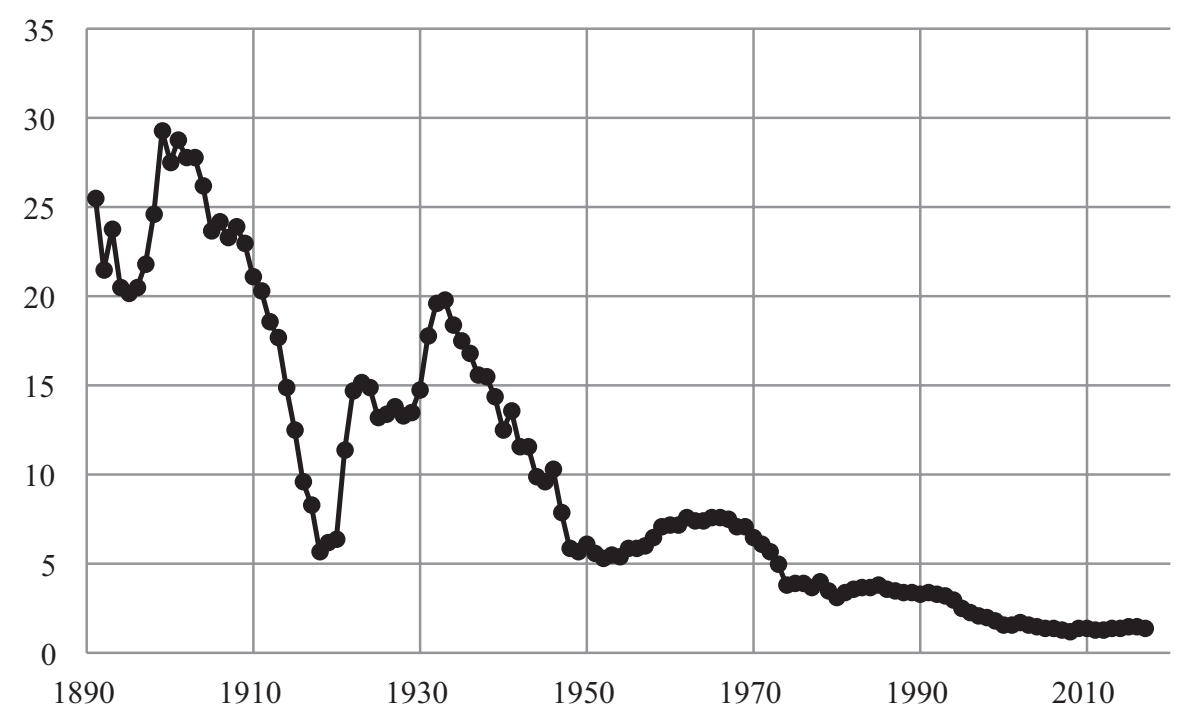

FIGURE 1

U.S. AVERAGE TARIFFS (DUTIES COLLECTED AS A SHARE OF TOTAL IMPORTS), $1891-2017$

Source: U.S. International Trade Commission, data available at https://www.usitc.gov/documents/ dataweb/ave_table_1891_2017.pdf (accessed 22 November 2018).

the twentieth century, but what there is finds evidence of deglobalization in the aftermath of the Great Depression. William Hynes, David Jacks, and O'Rourke (2012) use prices of agricultural commodities taken from the International Yearbook of Agricultural Statistics; Chris Hajzler and James MacGee (2015) use retail food prices in Canada and the United States. Both papers find evidence of increasing international price gaps during the 1930s. ${ }^{5}$ I am unaware of any similar evidence for the period since 2008 .

In summary, while the events of 2016 were dramatic, it is inaccurate to suggest that the world has, to date, experienced extensive deglobalization. That could still change in the future however. Even if it does not, no one could deny that the successful votes for Brexit and Trump, as well as the unsuccessful 2017 vote for the French National Front, the March 2018 election results in Italy, and support for populist parties elsewhere in Europe, represent a revolt against the established order in general and, at least in part, against globalization in particular. To what extent does economic history speak to the causes of this revolt, or help us to understand how to respond to it?

\footnotetext{
${ }^{5}$ On the other hand, Chilosi and Federico (2015) find little or no evidence of increasing EuroAsian price gaps during the interwar period.
} 


\section{THE LATE NINETEENTH CENTURY}

The argument that the populist revolts of 2016 represented, at least in part, a backlash against globalization rests on three assertions. First, the world economy became significantly more integrated after 1990, and particularly after 2001 when China entered the WTO. Second, this globalization had significant distributional effects. And third, those distributional effects ended up having political consequences. While there is little dispute about the first of these assertions, the second and third are hotly contested.

During the 1990s, economic historians tried to make precisely the same three-step argument to explain the anti-globalization backlash of the late nineteenth century. ${ }^{6}$ First, they argued that the late nineteenth century international economy was integrating at an impressive rate: that globalization, viewed as a process, was dramatic during this period. Technological change was largely responsible, notably steamships, railroads, and the telegraph (e.g., Garbade and Silber 1978; Harley 1988; O'Rourke and Williamson 1999; Hoag 2006; Pascali 2017; Juhász and Steinwender 2018). ${ }^{7}$ Political and geopolitical factors such as European imperialism which opened colonies to trade, the imposition of close to free trade on countries such as China and Japan which remained independent, the pax Britannica which ensured a relatively peaceful century in Europe (Schroeder 1994, p. vii), and (until the 1870s) trade liberalization in Europe also played an important role (Findlay and O'Rourke 2007, Chapter 7).

Following scholars such as Knick Harley (1980), O'Rourke and Williamson (1994) used price evidence to make the case for transAtlantic commodity markets, and they drew on work by other authors, such as A.J.H. Latham and Larry Neal (1983) and William Collins (1996), to make the case for commodity markets more generally. Taken in conjunction with the evidence on transport costs (Harley 1988) and trade volumes, it is clear that the nineteenth century saw a dramatic integration of commodity markets. It is also clear that international markets for labor and capital became much better integrated. By the end of the

\footnotetext{
${ }^{6}$ This three-step argument is perhaps most associated with a group of scholars associated with Williamson, including Boyer, Collins, Hatton, O'Rourke, Taylor, and Timmer. But several others - such as Bordo, Eichengreen, Goldin, Irwin, and Obstfeld - were working independently on various aspects of nineteenth century globalization at the time, and we were able to draw extensively on their research.

${ }^{7}$ On the other hand Jacks and Pendakur (2010) argue that falling maritime trade costs were not the primary driver of the nineteenth-century trade boom. Pascali also provides evidence in support of the main argument advanced by Williamson (2011).
} 
nineteenth century, more than one million Europeans were leaving the continent every year, and there were substantial outflows from China and India, as well. Foreign investments as a share of world GDP rose from 7 percent in 1870 to almost 20 percent on the eve of WWI (Hatton and Williamson 1998; Obstfeld and Taylor 2004).

\section{Trade and Income Distribution in the Late Nineteenth Century and Today}

Second, the 1990s literature argued that commodity market integration and mass migration had significant distributional effects, although these varied across countries. Let me start with trade. Ceteris paribus, narrowing commodity price gaps raised New World agricultural prices and European manufactured goods prices, while they lowered European agricultural prices and New World manufactured goods prices. O'Rourke and Williamson (1994) used computable general equilibrium (CGE) techniques to argue that these price shocks benefited abundant factors and hurt scarce factors, in classic Heckscher-Ohlin fashion. In particular, falling transport costs hurt British landowners and benefited British workers, while they boosted land rents in the United States. ${ }^{8}$ The impact was significantly bigger in Britain, reflecting its greater openness to international trade. O'Rourke, Alan Taylor, and Williamson (1996) provided econometric evidence for a small panel of seven "Atlantic economy" countries that relative goods prices were related to relative factor prices in line with Heckscher-Ohlin theory. Williamson (2002) broadened the argument to include what in the twentieth century came to be called the Third World.

Regarding the econometric approach of O'Rourke, Taylor, and Williamson (1996): a panel regression with seven countries and eight time periods might not strike people nowadays as providing particularly compelling evidence. On the other hand, it was at least a theoryconsistent econometric test of the Heckscher-Ohlin model, which is rare enough. Since this is a general equilibrium theory, which predicts a relationship between a vector of economy-wide goods prices and a vector of economy-wide factor prices, the appropriate unit of observation is the economy, rather than regions or industries. As Pinelopi Goldberg and Nina Pavcnik (2007, p. 58) say, "The general equilibrium nature of the Heckscher-Ohlin model makes it extremely hard to bring it to the data.

\footnotetext{
${ }^{8}$ Williamson (1990) had earlier produced broadly consistent estimates of the distributional impact of early nineteenth century British protection.
} 
Given that the model's predictions refer to economy-wide factor returns, one has only one observation per year to work with." Not surprisingly, therefore, later researchers such as Kris Mitchener and Se Yan (2014), when revisiting these issues, have established a link between trade (i.e., traded goods prices) and income distribution using model-based simulation methods.

The most influential work linking trade and income distribution today is, deservedly, the work of David Autor, David Dorn, and Gordon Hanson. Autor, Dorn, and Hanson (2013) show that U.S. regions which were more heavily exposed to rising Chinese import competition between 1990 and 2007 experienced higher unemployment, lower labor force participation, and lower wages. Since they "circumvent the degrees-offreedom problem endemic to estimating the labor-market consequences of trade" (p. 2124) by focusing on regions, they are not testing long-run Heckscher-Ohlin theory. On the other hand, their research suggests that the "short run" regional disequilibria arising from major trade shocks are much more persistent and severe than previously thought, and that we need to worry about these more than we once did. That, in turn, suggests an agenda for future historical research, assuming that the required regional data are available.

\section{Migration, Wages, and Employment in the Late Nineteenth Century and Today}

When it came to the impact of mass migration on income distribution, the literature of the 1990s used a similar mixture of techniques. Since the scholars involved were interested in economy-wide effects, there was the same degrees of freedom problem as that described earlier, and similar responses to the problem. George Boyer, Hatton, and O'Rourke (1994), O'Rourke, Williamson, and Hatton (1994) and O'Rourke and Williamson (1995) used CGE models. Taylor and Williamson (1997) assumed a three-factor (land, labor, and capital) production function, and estimated the elasticity of substitution econometrically using data for a panel of 14 countries. This elasticity, together with information on factor shares, yielded aggregate labor demand elasticities, which allowed them to estimate the wage impact of migration-induced labor supply shocks. For example, the 24 percent increase in the U.S. labor force between 1870 and 1910 was estimated to have lowered U.S. wages by 8 percent (O’Rourke and Williamson 1999, p. 155).

Other research tried to circumvent the degrees of freedom problem by using variation across cities or states, in particular in the United States. As 
in the case of trade, this approach cannot deal with the issue of whether or not there were economy-wide effects of immigration on wages. On the other hand, such studies may pick up a local effect if intra-regional labor market adjustment is sluggish, as the work of Autor, Dorn, and Hanson (2013) suggest is the case today.

By and large, the literature suggests that nineteenth-century immigration put pressure on local U.S. labor markets. Hatton and Williamson (1998, Chapter 8) found that higher rates of immigration were correlated across U.S. states with higher rates of native-born out-migration, controlling for a variety of other factors, while Collins (1997) found a negative correlation between foreign-born and African-American net migration to a sample of northern U.S. states and cities. Claudia Goldin (1994) found a negative city-level relationship between wages and the proportion of the population that was foreign-born: a 1 percent increase in the latter lowered wages between 1 and 1.5 percent, an effect big enough that it cannot plausibly be attributed to composition effects (as noted by Hatton and Zachary Ward 2018), and notable in the context of the evidence on intra-regional labor market adjustment provided by Collins, Hatton, and Williamson.

There is a vigorous debate regarding whether present-day immigration lowers wages or employment levels. To take some recent examples, Gianmarco Ottaviano and Giovanni Peri (2012) find that immigration into the United States between 1990 and 2006 had a small positive effect on native wages, but lowered the wages of previous immigrants; Marco Manacorda, Alan Manning, and Jonathan Wadsworth (2012) find broadly similar evidence for immigration into the United Kingdom from the 1970s to the 2000s; Christian Dustmann, Tommaso Frattini, and Ian Preston (2013) find that immigration between 1997 and 2005 lowered the wages of native-born U.K. workers below the 20th percentile of the wage distribution, but slightly increased the wages of well-paid workers; and Dustmann, Uta Schönberg, and Jan Stuhler (2017) find that immigration in 1991 had a moderate negative impact on local native-born German wages, and a significant negative impact on native employment.

Such mixed evidence stands in contrast to the unambiguous conclusions of the 1990s literature on late nineteenth-century migration. Is this contrast due to different types of data and research methodologies, or to different historical contexts? One obvious historical difference concerns the proportional scale of migration flows: Taylor and Williamson (1997) estimate that immigration raised labor supply by 24 percent in the United States, 44 percent in Canada, and 86 percent in Argentina. It would be odd if such enormous flows had not had an impact, even if only 
counterfactual, on wages. More speculatively, the size of the flows may have made it easier to identify wage elasticities by shifting labor supply curves to a greater extent.

Ran Abramitzky and Leah Platt Boustan (2017) list several reasons why the elasticity of wages with respect to immigration might have been larger in the United States a hundred years ago than today: greater similarity in the labor market characteristics of immigrants and natives; less employment in the service sector, where the impact on wages might be muted; or a similar regulatory framework (involving not much regulation) for both categories of workers, rather than segmentation between legal and illegal workers. Bin Xie (2017) further suggests that manufacturing jobs may have been more homogenous then than now, implying less scope for natives to specialize so as to avoid competition from immigrants; and (citing Rosenbloom (1996)) that inter-regional mobility within the United States may have been less strong in the nineteenth century, implying greater local impacts for econometricians to find. Modern minimum wage laws are another reason why wage effects might be smaller today than a hundred years ago.

Having said that, Abramitzky and Boustan's (2017) judgment that immigration "creates winners and losers in the native population and among existing immigrant workers, reducing the wages of low-skilled natives, encouraging some native born to move away from immigrant gateway cities, and spurring capital investment" seems reasonable. So does the frequent finding that the greatest negative wage impacts of immigration may be felt by previous immigrants. We might expect the short- and long-run impacts of immigration to be different, with accumulation and technological responses to immigration potentially muting its wage impact (for a survey, see Lewis (2013)). We might also expect the impact of immigration to vary depending on the nature of the flows and the institutional and economic context.

Abramitzky and Boustan are surely right to call for more research, using modern techniques, on the labor market impact of migration during the late nineteenth century. Recent studies for the interwar and early postwar periods show the way. Consistent with the 1990s research on the nineteenth century, Xie (2017) finds that U.S. immigration restrictions raised manufacturing wages and promoted South to North migration by African Americans during the 1920s; less consistent are Philipp Ager and Casper Worm Hansen (2017), who also use quotas as an identification strategy, but rely on occupational data, finding that while quotas boosted the status of African Americans, they pushed native whites into lower wage occupations; even less consistent are Alan Green and David Green (2016), 
who find only small effects of immigration on Canadian wages during the 1920 s, once general equilibrium adjustments are taken into account; Marco Tabellini (2019), who finds only very small (and not statistically significant) effects on manufacturing wages of immigration in a panel of U.S. cities between 1910 and 1930; and Michael A. Clemens, Ethan Lewis, and Hannah Postel (2018), who find that the exclusion of almost half a million Mexican farm workers from the United States at the end of 1964 failed to substantially raise the wages of native-born workers. The evidence is thus mixed, as it is for the modern period.

In summary, the literature on the late nineteenth century found that globalization created both winners and losers, with the most prominent losers being European landowners and native-born New World workers. What was the political impact of this?

\section{Backlash in the Late Nineteenth Century and Today}

The third step in the argument that late nineteenth-century globalization undermined itself was that the distributional effects of migration and trade led to an anti-globalization backlash. When using regional data to test whether trade or migration are linked to voting behavior at the local level, there is a problem analogous to the "degrees of freedom" issue discussed earlier. Such exercises will miss any national-level political effects of globalization operating equally across districts. Despite this, when Goldin (1994) studied 1915 Congressional voting on the U.S. Literacy Test, she found that higher local wage growth lowered the likelihood of an anti-immigration vote. Timmer and Williamson (1998) developed a cross-country index of immigration policy for a panel of countries, and found that policy became less restrictive the higher were unskilled wages relative to average incomes. Put these findings together with those on the impact of immigration on wages, and you have a clear case of a dimension of globalization (in this case migration) undermining itself.

The 1990s evidence on the determinants of nineteenth-century trade policy was more qualitative, although it was able to draw on an extensive political science literature, such as Peter Gourevitch (1977) and Ronald Rogowski (1989). O'Rourke (1997) argued that the more liberal trade policy responses of the United Kingdom and Denmark to the grain invasion could be explained by the different distributional effects it had in those two countries based on CGE evidence. Another approach is to study election results in settings where trade was the dominant issue to see whether votes on trade policy are consistent with economic interests. The typical finding of authors such as Douglas Irwin (1994) is that economic 
interests matter. He finds a role for sectoral interests in explaining why the United Kingdom did not revert to protectionism in 1906. Sibylle Lehmann (2010) uses ecological inference methods and concludes that while small farmers favored free trade in the 1878 German election, large estate owners favored protection, which is in line with Heckscher-Ohlin theory. On the other hand, the fact that smaller farmers shifted towards protectionist candidates in Sweden in 1887 seems puzzling. Lehmann and Oliver Volckart (2011) interpret that shift as representing a loss of trust in the incumbent government, a reminder that even in elections where trade is a major issue votes are cast for many reasons. ${ }^{9}$

The question of whether the electoral upsets of 2016 were due to economic factors, and in particular whether they represented an antiglobalization backlash, is fiercely disputed. Some have argued that the causes were cultural, but if the causes were purely cultural one has to ask what it was that led working class voters to become more culturally conservative in the United Kingdom, United States, France, Italy, and elsewhere over the course of the last 10 or 15 years. As historians, economic historians are presumably comfortable with complexity. Think of the debate about why Robert Peel repealed the Corn Laws: Was this due to ideas or interests? A long literature, expertly summarized by Cheryl Schonhardt-Bailey (2006), has shown that it was much more complicated than that. Yes, there is evidence that Members of Parliament voted in their own economic interests, and in the economic interests of their constituents. The lobbying of interest groups mattered, as did the diversification of landlords' portfolios. But Peel's ideas about the determinants of wages also mattered (Irwin 1989), as did his sense of ethics, and the ability of the Duke of Wellington to deliver the House of Lords, and the constitutional reasons why the Duke decided to do so, and so on. Imagine our successors looking back at our own period in 50 years' time, and asking students whether the turmoil of 2016 was due more to economics or to culture. Is it not likely that the answer to that question will be the same as it usually is, when students are given the choice between two pedagogically useful but overly simplistic alternativesthat it was, in fact, a bit of both?

As indicated previously, my view is that economic historians have done a reasonable job of showing that late nineteenth-century globalization undermined itself by creating both winners and losers, with the latter successfully influencing trade or migration policies in several countries. But economics was not the only factor at work even then.

\footnotetext{
${ }^{9}$ See also Williamson (2006).
} 
Yes, immigration restrictions in the United States were linked to the impact of immigration on wages, but even a cursory examination of the relevant legislation shows an obsessive concern with Asian immigration in particular. No-one reading Avner Offer's (1989) account of how anti-Asian racism was ubiquitous throughout the late nineteenthcentury Anglosphere could be in any doubt that "culture" was a powerful factor underlying late nineteenth-century immigration restrictions. But economics mattered also.

Can you fully understand Brexit without taking account of English nationalism, or the obsessive hostility towards Obama without reference to the color of his skin (on the former, see O'Rourke (2018b, Chapter 9))? Surely not, but at the same time, evidence suggests that economic factors were also important during 2016. This does not automatically mean that voters were being "rational," in the sense that they were voting in their own economic self-interest. Take, for example, the evidence presented by Sascha O. Becker, Thiemo Fetzer, and Dennis Novy (2017) and Fetzer (2018) showing a clear link between austerity policies and the pro-Brexit vote in Britain. This is a good example of economically motivated voting, but it is not a good example of economically rational voting for the simple reason that Conservative austerity policies had nothing to do with the EU.

However, other evidence on twenty-first century voting behavior is more consistent with the late nineteenth-century anti-globalization backlash narrative. Becker, Fetzer, and Novy find that migrant inflows from Eastern Europe were correlated with the pro-Brexit vote, though the effect is small. Italo Colantone and Piero Stanig (2018) find that the Brexit vote was significantly higher in regions that were more exposed to Chinese import competition. Autor et al. (2016) find that increased imports from China were associated with political polarization at the Congressional district level in the United States from 2000 onwards. Taken in conjunction with their evidence, cited earlier, on the impact of Chinese imports on local labor market outcomes, and you have a compelling argument linking globalization to both economic outcomes and political change. The precise mechanism is unclear, however. Some Trump supporters were presumably voting in favor of protection, in the manner of nineteenth-century European landowners. However, as Autor et al. note, populist voters could also have been voting for politicians promising a greater slice of the public service pie for white voters at a time of increased competition for government services. Alternatively, populist politicians could have opportunistically responded to economic hard times by supplying extremist policies designed to increase voter 
turnout and campaign contributions (Autor et al. 2016, p. 4). The literature on the link between economic distress and populism is too vast to be summarized here, but a reasonable conclusion is that trade and immigration have contributed to the surge of populism in Europe and America.

\section{What Is to Be Done?}

One shortcoming of O'Rourke and Williamson (1999), in my opinion, is that its view of the political process was excessively simplistic. Politics was effectively reduced to a binary choice: governments could choose to stay open, or not. They remained open where the configuration of interests permitted it, and they erected barriers to trade or immigration otherwise. A practicing politician might find suggestions regarding how to maintain openness in the face of protectionist pressures more useful.

This is where the work of Michael Huberman and co-authors comes in. In a series of articles and a subsequent book (Huberman 2012), Huberman describes the gradual introduction, during the late nineteenth century, of labor market regulations and social insurance programs designed to protect workers. In some cases, notably Belgium, workers' support for trade liberalization was conditional on the introduction of this "labor compact." Importantly, the labor compact was more advanced in countries more open to trade: there was no sign of globalization leading to a race to the bottom during this period. This mirrors the finding of Dani Rodrik (1998) that more open economies had bigger governments in the late 1980s and early 1990s. Rodrik interprets this correlation as reflecting a higher demand for the insurance services provided by the government sector in countries more exposed to trade shocks.

In this view, states and markets are complements rather than substitutes, in that state action can help to maintain political support for openness. It is possible that financial globalization and greater competition for mobile direct investment may today be placing constraints on the ability of states to finance such policies (Rodrik 2017). On the other hand, there has surely never been a more tightly integrated group of economies in human history than the 28 - soon to be 27 - member states of the EU. Despite the hyper-globalization linking its members, the EU seems to be able to accommodate wildly differing preferences regarding the share of GDP going to government. Setting aside Ireland, whose GDP statistics are not comparable with those in other countries, general government expenditure as a share of GDP ranged in 2016 from a low of 34 percent in Romania to a high of 56.4 percent in France. The ratio was less than 40 
percent in eight member states, and higher than 50 percent in five. ${ }^{10}$ The late nineteenth-century lesson that globalization and pro-worker state intervention can go hand in hand may not be out of date yet.

Economic history also suggests that states can directly cooperate with each other to avoid mutually harmful regulatory races to the bottom that might undermine support for openness. Huberman and Christopher Meissner (2010) discuss how countries traded market access in return for promises to strengthen regulatory standards during the late nineteenth century. The 1904 agreement between France and Italy also linked regulatory standards and migration: France allowed Italian immigrants to benefit from the French labor compact, on condition that Italy bring its own regulatory standards up to international levels. Alan Milward (2000) emphasized that European integration was an essential part of that continent's response to the traumas of the interwar period, since it boosted the capacity of states to deal with the problems facing them. It was important for countries to be able to reap the benefits of trade, but this could not come at the expense of broader social and political objectives. "The problem genuinely was how to construct a commercial framework which would not endanger the levels of social welfare which had been reached ... The Treaties of Rome had to be also an external buttress to the welfare state" (Milward 2000, p. 216). And so the Treaty of Rome (1957) envisaged not just a customs union, but inter alia a Common Agricultural Policy, regional policy, and the harmonization of social policies. The supranational elements of the European project were a logical consequence. These always bothered the British, but they were (and still are) seen as essential in maintaining popular support for European economic integration (O’Rourke 2018b).

\section{THE GREAT DEPRESSION}

O'Rourke and Williamson suggest that the deglobalization of the interwar period was not solely the result of an exogenous shock, namely the Great War, but had its roots in the anti-globalization backlash of the late nineteenth century $(1999$, p. 286). We did not discuss in detail the extent to which this was really the case, but it merits reflection. I think that we were on fairly solid ground, for example, when it comes to U.S. immigration policies. There is a clear continuity between the gradually tightening restrictions over the course of the late nineteenth century, the introduction of the U.S. Immigration Act of 1917, and the immigration

\footnotetext{
${ }^{10} \mathrm{http}: / /$ ec.europa.eu/eurostat/web/products-datasets/-/tec00023
} 
quotas of the 1920s. The European agricultural protection introduced before 1914 survived the war intact, and remains with us today. The late nineteenth century also saw a shift towards protecting heavy industry in particular, and manufacturing more generally, from British competition. This phenomenon was so ubiquitous that Robert Allen (2011) describes it as being part of a developmental "standard model." It was adopted by countries across the globe as they regained tariff autonomy in the twentieth century.

On the other hand, it would be wrong to suggest that the outbreak of WWI and the onset of the Great Depression did not represent important discontinuities that had serious negative consequences for the openness of the world economy. To what extent could either of these be regarded as examples of globalization undermining itself, as opposed to exogenous shocks imposed upon an otherwise robust and open international system?

Let me start with the Depression. We know from Peter Temin (1989) and Barry Eichengreen (1992) that the gold standard and Great Depression were inextricably linked. The gold standard was part of the institutional infrastructure underpinning global capital markets during the late nineteenth century. Going back on gold in the 1920s was an important part of the attempt to recreate the highly globalized pre-war world, and was seen by politicians as signaling a commitment to a generally open international system. To that extent, you could regard the Great Depression that followed as being caused by 1920 s globalization. Perhaps that is a slightly forced argument. A more compelling reason to view the Depression as having been caused, at least to some extent, by the globalization that preceded it, is the role played by international capital flows in transmitting the crisis around the world. This was presumably always self-evident to scholars of countries such as Germany, and was a central focus of Charles Kindleberger (1973), but I think that Anglo-Saxon economic historians have tended, since the work of Eichengreen and Temin, to think about the Depression more in Mundell-Fleming terms, with exchange rates, interest rates, and monetary and fiscal policy being at the heart of the analysis. This tendency fits well with Keynes's repeated denunciations of interwar macroeconomic policy-making. Since 2008, however, and in particular since the Eurozone crisis of 2010, it has become more natural to once again think of the Depression in Europe in terms of a sudden stop of capital flows, a perspective recently exemplified by Olivier Accominotti and Eichengreen (2016). Seen in this perspective, the Great Depression in Europe appears more clearly as a negative consequence of a particular dimension of globalization, namely capital mobility: When the lending stopped, countries like Germany found themselves obliged 
to cut expenditure, while their financial systems came under strain as foreign depositors withdrew money from banks (Eichengreen 2015, pp. 137-44). And perhaps the German historical literature debating whether Chancellor Brüning, widely criticized for his economically and politically destructive austerity policies, could have behaved in a less dangerous manner resonates more strongly today than it once did to observers of the Eurozone periphery.

To the extent that the Depression was caused by malfunctioning international capital markets, or the gold standard that was thought at the time to underpin them, we have yet another case of globalization undermining itself, since the Depression was the major cause of interwar protectionism (Smoot-Hawley, which had its roots earlier, notwithstanding). Eichengreen and Irwin (2010) show that protectionism during the 1930s was associated with adherence to the gold standard, a point that had earlier been noted by, among others, the League of Nations (1943, p. 31). Staying on gold longer meant balance of payments problems and a more protracted depression, and doing so deprived policymakers of alternative ways of addressing these problems.

Even worse, the Depression promoted political extremism, notably but not only in Germany. Gregori Galofré-Vilà et al. (2017) find that austerity was positively correlated with the Nazi vote in Germany between 1930 and 1933, but there is econometric evidence linking economic crises with right-wing extremism more generally. Alan de Bromhead, Eichengreen, and O'Rourke (2013) find evidence that protracted periods of poor economic performance were associated with higher votes for right wing political extremists in the interwar period, while Manuel Funke, Moritz Schularik, and Christoph Trebesch (2016) find, in a sample of 20 advanced economies between 1870 and 2014, that far-right parties increased their vote share by 30 percent on average following financial crises. Nationalist extremism fueled even more dramatic deglobalization, as the Nazis developed a tightly controlled war economy characterized by the search for strategic self-sufficiency and bilateral trading arrangements (Tooze 2006).

What could have prevented these disasters? Superior macroeconomic policy-making is the obvious answer: countries could have chosen to go off gold earlier, preferably in a coordinated manner, and used the resultant policy flexibility to reflate their economies. To that extent, the global policy response after 2008 was far superior. The experience of the Eurozone periphery after 2010, when countries found themselves unable to devalue, obliged to engage in procyclical austerity, and (until Mario Draghi took over the reins of the European Central Bank) locked into a 
monetary union pursuing excessively conservative policies, shows that these basic macroeconomic lessons of the Great Depression still have relevance (O'Rourke and Taylor 2013). That experience surely helps to explain the election of a populist Italian government in 2017.

\section{WORLD WAR I}

Finally, what about WWI? Adam Tooze and Ted Fertik (2014) argue that we should not regard it as having ended the globalization of the late nineteenth century, since it was itself a globalised conflict, involving high levels of international borrowing and lending and the large-scale transfer of military resources between continents. The point is well made. On the other hand, the available price evidence suggests an impressive disintegration of international commodity markets during the war (Findlay and O'Rourke 2007, p. 434), while the conflict had a host of longer-run consequences, ranging from the creation of new nation states in eastern Europe, to structural imbalances affecting industries and agricultural sectors worldwide, to the Russian Revolution, all of which helped to ensure that it would be difficult to recreate the cosmopolitan international economic order that had, by and large, obtained before 1914 (ibid., pp. 435-43). Some interwar restrictions on trade and migration had their roots in the late nineteenth century, but the Great War had an independent disintegrating impact on the international economy.

To what extent should we think of the war as an exogenous shock hitting the world economy in 1914 ? Or did it represent, at least to some extent, an even more dramatic form of anti-globalization backlash? Tooze and Fertik (2014) make what is perhaps the most direct connection between globalization and war: capital flows and technology transfer helped Russia converge on the established powers. This disrupted preexisting geopolitical equilibria and led Germany in particular to devise military strategies to counter the threat. They could have added that the spread of the Industrial Revolution to Germany had earlier undermined the geopolitical equilibrium in Europe, perhaps to an even more fundamental extent. Similarly, the spread of modern growth to Japan undermined Asian stability in the first half of the twentieth century. If there is an analogy with today it is both obvious and worrying: few would dispute that Chinese growth has been intimately linked to globalization or that this will have consequences for the international balance of power.

David Rowe (2005) suggests a more subtle mechanism linking pre-WWI globalization with the outbreak of that conflict. Globalization raised wages throughout labor-abundant Europe, raising the financial cost 
of recruiting soldiers or the political cost of conscripting them. This made states feel more insecure militarily and less able to credibly threaten military retaliation. It also made them worry about the reliability of their military allies. All these factors, according to Rowe, help to explain the catastrophic series of political decisions that were made in the run-up to war.

Another mechanism linking late nineteenth-century globalization to geopolitical instability is suggested by Offer (1989). Structural change, magnified by international trade which allowed industrializing countries to reap the benefits of comparative advantage, led first the United Kingdom, and later Germany, to become increasingly dependent on imported supplies of food and raw materials. This dependence made countries feel militarily vulnerable, and made naval superiority — or, in the case of Germany, as close to naval parity as was feasible - a matter of vital national strategic interest. The Anglo-German naval rivalry of the decades prior to 1914 was a logical consequence. Offer shows how naval strategists were motivated first by purely defensive considerations, but later began to explore the offensive possibilities of naval warfare (see also Lambert 2012). These considerations were of course not responsible for the outbreak of WWI, but they were at least in part responsible for the U.K.'s decision to enter the war. If Germany defeated France, it would be able to project continental-scale power directly into the Atlantic, safe from the threat of British blockade. As Sir Edward Grey said in 1911, if a European power achieved continental hegemony Britain would permanently lose its control of the sea, which would in turn mean its separation from the Dominions and the end of Empire (Howard 1972, pp. 51-52).

Tooze (2006) and Michael Barnhart (1987) have shown how a concern to achieve strategic self-sufficiency was both a cause and an effect of the drive to war during the interwar period in Germany and Japan respectively. Roberto Bonfatti and O'Rourke (2018) show more generally how a follower country's strategic dependence on imported raw materials can, in conjunction with the naval hegemony of an established power, give the follower country an incentive to launch pre-emptive wars in the hope of gaining strategic self-sufficiency. Higher costs of war in high-wage globalized economies can also give politicians an incentive to gamble on rapid offensives, in the hope of striking a knockout blow (Eloranta and Harrison 2010, p. 137).

Again, if there is a contemporary parallel, it is with China. Like Britain and Germany in the nineteenth century, it has been undergoing rapid industrialization and structural change, and it has become far more dependent on international trade. On the import side, it relies heavily on 
foreign oil, much of which passes through the Straits of Malacca; on the export side, it has toyed with using its near monopoly of rare earths for strategic purposes. The international state system has a poor record of peacefully accommodating the arrival of newcomers to the top table, and there is a fascinating theoretical and historical literature on the topic that is too vast to be summarized here (e.g., Gilpin 1981; Powell 2006). If China started to doubt that it could rely on the market to provide it with the food and raw materials it requires, the world could become a much more dangerous place.

One of the features of interwar trade that struck contemporary observers as particularly dangerous was its decreasingly multilateral nature, with countries trading more and more with their colonial possessions or spheres of influence. As Folke Hilgerdt (1935, p. 188) put it, "As bilateralism particularly renders the supply of raw materials to certain countries difficult, it threatens to lead to an intensified fight for influence upon (or the domination of) the undeveloped countries, and thereby to political controversies, which may adversely affect all forms of peaceful collaboration between nations." de Bromhead et al. (2019) show that discriminatory U.K. trade policies can explain more than 70 percent of the increase in the British Empire's share of U.K. imports after 1930. And so it is no surprise that Article 1 of the GATT prohibited discriminatory trade policies, subject to a number of well-known exceptions. The interwar period suggests that the greatest costs of aggressive and discriminatory trade policies can be political rather than economic. It is in this context that upholding the international rule of law is so important, and that the implications of Brexit and Trump become potentially alarming. In particular, the U.S. refusal to reappoint judges to the WTO's Appellate Body threatens to render the work of that body impossible.

\section{CONCLUSION}

The world has not yet experienced extensive deglobalization, but it could in the future, with dangerous geopolitical consequences. What should policy makers do?

Fortunately, the lessons of the Great Depression influenced macroeconomic policy after 2008, but they are not the only relevant lessons of history. The political upsets of 2016 occurred in the United States and the United Kingdom, where post-crisis macroeconomic management was far superior to that in the Eurozone, and where recoveries came correspondingly sooner. This suggests that longer-run forces, linked to trade and 
migration, may be having a greater impact on voting than the post-2008 macroeconomic and financial crisis. Is it a coincidence that the upsets of 2016 occurred in countries where the twenty-first century equivalent of Huberman's labor compact has been eroded the most? My reading of history suggests that if governments push anything too far, including markets in general, and globalization in particular, a reaction is to be expected. Rather than promoting ever-closer integration in an already highly globalized world, maybe advocates of openness should declare victory and focus on how to protect individuals and regions from the risks that markets, both domestic and international, inevitably give rise to.

There is a final contribution that economic historians, like all historians, can bring to present-day debates about the political upsets of 2016, the causes of populism more generally, and the potential implicationssome of which are very worrying - for the international order. As economists, we are trained to look for patterns and to seek general explanations for entire classes of phenomena rather than specific explanations for individual historical events. But as historians we are trained to recognize the uniqueness of individual events and acknowledge the roles played in them by context, contingency, and the choices made by individual actors. This is the creative tension that lies at the heart of our discipline and makes it so fascinating. And the perspective of the historian is important today, since it reminds us that we and our leaders enjoy free will, which we can exercise for better or for worse. Nothing is inevitable. In dangerous times that is a useful thought to bear in mind.

\section{REFERENCES}

Abramitzky, Ran, and Leah Platt Boustan. "Immigration in American Economic History." Journal of Economic Literature 55, no. 4 (2017): 1311-45.

Abu-Lughod, Janet L. Before European Hegemony : The World System A.D. 12501350. New York and Oxford: Oxford University Press, 1989.

Accominotti, Olivier, and Barry Eichengreen. "The Mother of All Sudden Stops: Capital Flows and Reversals in Europe, 1919-32." Economic History Review 69, no. 2 (2016): 469-92.

Ager, Philipp, and Casper Worm Hansen. "Closing Heaven's Door: Evidence from the 1920s U.S. Immigration Quota Acts." University of Copenhagen Department of Economics Discussion Papers No. 17-22, Copenhagen, Denmark, 2017.

Allcott, Hunt, and Matthew Gentzkow. "Social Media and Fake News in the 2016 Election." Journal of Economic Perspectives 31, no. 2 (2017): 211-36.

Allen, Robert C. Global Economic History: A Very Short Introduction. Oxford: Oxford University Press, 2011. 
Anderson, James E., and J. Peter Neary. Measuring the Restrictiveness of International Trade Policy. Cambridge, MA and London: MIT Press, 2005.

Autor, David H., David Dorn, and Gordon H. Hanson. "The China Syndrome: Local Labor Market Effects of Import Competition in the United States." American Economic Review 103, no. 6 (2013): 2121-68.

Autor, David, David Dorn, Gordon Hanson, et al. "Importing Political Polarization? The Electoral Consequences of Rising Trade Exposure." NBER Working Paper No. 22637, Cambridge, MA, September 2016.

Bairoch, Paul. "European Trade Policy, 1815-1914." In The Cambridge Economic History of Europe Vol. VIII, edited by Peter Mathias and Sidney Pollard, 1-160. Cambridge: Cambridge University Press, 1989.

Barnhart, Michael A. Japan Prepares for Total War: The Search for Economic Security, 1919-1941. Ithaca and London: Cornell University Press, 1987.

Becker, Sascha O., Thiemo Fetzer, and Dennis Novy. "Who Voted for Brexit? A Comprehensive District-Level Analysis.” Economic Policy 32, no. 92 (2017): 601-50.

Bonfatti, Roberto, and Kevin Hjortshøj O'Rourke. "Growth, Import Dependence, and War." Economic Journal 128, no. 614 (2018): 2222-57.

Boyer, George R., Timothy J. Hatton, and Kevin O'Rourke. "The Impact of Emigration on Real Wages in Ireland." In Migration and the International Labor Market, 1850-1939, edited by Timothy J. Hatton and Jeffrey G. Williamson, 221-39. London: Routledge, 1994.

Chilosi, David, and Giovanni Federico. "Early Globalizations: The Integration of Asia in the World Economy, 1800-1938." Explorations in Economic History 57 (2015): $1-18$.

Clemens, Michael A., Ethan G. Lewis, and Hannah M. Postel. "Immigration Restrictions as Active Labor Market Policy: Evidence from the Mexican Bracero Exclusion." American Economic Review 108, no. 6 (2018): 1468-87.

Colantone, Italo, and Piero Stanig. "Global Competition and Brexit." American Political Science Review 112, no. 2 (2018): 201-18.

Collins, William J. "Regional Labor Markets in British India.” Unpublished Manuscript. Department of Economics, Harvard University, Cambridge, MA, 1996.

—. "When the Tide Turned: Immigration and the Delay of the Great Black Migration." Journal of Economic History 57, no. 3 (1997): 607-32.

de Bromhead, Alan, Barry Eichengreen, and Kevin H. O'Rourke. "Political Extremism in the 1920s and 1930s: Do German Lessons Generalize?" Journal of Economic History 73, no. 2 (2013): 371-406.

de Bromhead, Alan, Alan Fernihough, Markus Lampe, et al. "When Britain Turned Inward: The Impact of Interwar British Protection." American Economic Review 109, no. 2 (2019): 325-52.

de Zwart, Pim. "Globalization in the Early Modern Era: New Evidence from the DutchAsiatic Trade, C. 1600-1800." Journal of Economic History 76, no. 2 (2016): $520-58$.

Dhingra, Swati, Hanwei Huang, Gianmarco Ottaviano, et al. "The Costs and Benefits of Leaving the EU: Trade Effects." Economic Policy 32, no. 92 (2017): 651-705.

Dustmann, Christian, Tommaso Frattini, and Ian P. Preston. "The Effect of Immigration along the Distribution of Wages.” Review of Economic Studies 80, no. 1 (2013): $145-73$. 
Dustmann, Christian, Uta Schönberg, and Jan Stuhler. "Labor Supply Shocks, Native Wages, and the Adjustment of Local Employment." Quarterly Journal of Economics 132, no. 1 (2017): 435-83.

Eichengreen, Barry J. Golden Fetters: The Gold Standard and the Great Depression, 1919-1939. New York and Oxford: Oxford University Press, 1992.

- Hall of Mirrors: The Great Depression, the Great Recession, and the Uses and Misuses - of History. New York: Oxford University Press, 2015.

Eichengreen, Barry, and Douglas A. Irwin. "The Slide to Protectionism in the Great Depression: Who Succumbed and Why?" Journal of Economic History 70, no. 4 (2010): 871-97.

Eloranta, Jari, and Mark Harrison. "War and Disintegration, 1914-1950." In The Cambridge Economic History of Modern Europe: Volume 2: 1870 to the Present, edited by Kevin H. O'Rourke and Stephen Broadberry, 133-55. Cambridge: Cambridge University Press, 2010.

Federico, Giovanni. "Market Integration." In Handbook of Cliometrics, edited by Claude Diebolt and Michael Haupert, 1-26. Berlin, Heidelberg: Springer Berlin Heidelberg, 2018.

Fetzer, Thiemo. "Did Austerity Cause Brexit?" Warwick Economics Research Paper No. 1170, University of Warwick, Coventry, U.K., July 2018.

Findlay, Ronald, and Kevin H. O'Rourke. Power and Plenty: Trade, War, and the World Economy in the Second Millennium. Princeton, NJ and Woodstock, Oxfordshire, England: Princeton University Press, 2007.

Flynn, Dennis O., and Arturo Giráldez. "Path Dependence, Time Lags and the Birth of Globalisation: A Critique of O'Rourke and Williamson." European Review of Economic History 8, no. 1 (2004): 81-108.

Funke, Manuel, Moritz Schularick, and Christoph Trebesch. "Going to Extremes: Politics after Financial Crises, 1870-2014." European Economic Review 88 (2016): 227-60.

Galofré-Vilà, Gregori, Christopher M. Meissner, Martin McKee, et al. "Austerity and the Rise of the Nazi Party." NBER Working Paper No. 24106, Cambridge, MA, December 2017.

Garbade, Kenneth D., and William L. Silber. "Technology, Communication and the Performance of Financial Markets: 1840-1975." Journal of Finance 33, no. 3 (1978): 819-32.

Gilpin, Robert. War and Change in World Politics. Cambridge: Cambridge University Press, 1981.

Goldberg, Pinelopi Koujianou, and Nina Pavcnik. "Distributional Effects of Globalization in Developing Countries.” Journal of Economic Literature 45, no. 1 (2007): 39-82.

Goldin, Claudia. "The Political Economy of Immigration Restriction in the United States, 1890 to 1921." In The Regulated Economy: A Historical Approach to Political Economy, edited by Claudia Goldin and Gary D. Libecap, 223-58. Chicago: University of Chicago Press, 1994.

Gourevitch, Peter Alexis. "International Trade, Domestic Coalitions, and Liberty: Comparative Responses to the Crisis of 1873-1896." Journal of Interdisciplinary History 8, no. 2 (1977): 281-313.

Green, Alan G., and David A. Green. "Immigration and the Canadian Earnings Distribution in the First Half of the Twentieth Century." Journal of Economic History 76, no. 2 (2016): 387-426. 
Hajzler, Chris, and James MacGee. "Retail Price Differences across United States and Canadian Cities During the Interwar Period.” EPRI Working Paper No. 2015-3, Western University, London, Ontario, Canada, 2015.

Harley, C. Knick. "Transportation, the World Wheat Trade, and the Kuznets Cycle, 1850-1913." Explorations in Economic History 17, no. 3 (1980): 218-50.

_. "Ocean Freight Rates and Productivity, 1740-1913: The Primacy of Mechanical Invention Reaffirmed.” Journal of Economic History 48, no. 4 (1988): 851-76.

Hatton, Timothy J., and Zachary Ward. "International Migration in the Atlantic Economy 1850-1940." In Handbook of Cliometrics, edited by Claude Diebolt and Michael Haupert. Berlin, Heidelberg: Springer Berlin Heidelberg, forthcoming, 2019.

Hatton, Timothy J., and Jeffrey G. Williamson. The Age of Mass Migration: Causes and Economic Impact. New York and Oxford: Oxford University Press, 1998.

Hilgerdt, Folke. "The Approach to Bilateralism - A Change in the Structure of World Trade.” Index X, no. 8 (1935): 175-88.

Hirst, Paul Q., and Grahame Thompson. Globalization in Question: The International Economy and the Possibilities of Governance. Cambridge: Polity Press, 1996.

Hoag, Christopher. "The Atlantic Telegraph Cable and Capital Market Information Flows." Journal of Economic History 66, no. 2 (2006): 342-53.

Howard, Michael. The Continental Commitment: The Dilemma of British Defence Policy in the Era of the Two World Wars, Ford Lectures. London: Maurice Temple Smith Ltd, 1972.

Huberman, Michael. Odd Couple: International Trade and Labor Standards in History. New Haven, CT: Yale University Press, 2012.

Huberman, Michael, and Christopher M. Meissner. "Riding the Wave of Trade: The Rise of Labor Regulation in the Golden Age of Globalization." Journal of Economic History 70, no. 3 (2010): 657-85.

Hynes, William, David S. Jacks, and Kevin H. O'Rourke. "Commodity Market Disintegration in the Interwar Period." European Review of Economic History 16, no. 2 (2012): 119-43.

Inglehart, Ronald, and Pippa Norris. "Trump, Brexit, and the Rise of Populism: Economic Have-Nots and Cultural Backlash." HKS Faculty Research Working Paper No. RWP16-026, Harvard Kennedy School, Cambridge, MA, August 2016.

Irwin, Douglas A. "Political Economy and Peel's Repeal of the Corn Laws." Economics \& Politics 1, no. 1 (1989): 41-59.

—. "The Political Economy of Free Trade: Voting in the British General Election of 1906." Journal of Law and Economics 37, no. 1 (1994): 75-108.

Jacks, David S., and Krishna Pendakur. "Global Trade and the Maritime Transport Revolution." Review of Economics and Statistics 92, no. 4 (2010): 745-55.

James, Harold. The End of Globalization: Lessons from the Great Depression. Cambridge, MA and London: Harvard University Press, 2001.

Juhász, Réka, and Claudia Steinwender. "Spinning the Web: The Impact of ICT on Trade in Intermediates and Technology Diffusion." NBER Working Paper No. 24590, Cambridge, MA, May 2018.

Kindleberger, Charles P. The World in Depression, 1929-1939. London: Allen Lane, 1973.

Lambert, Nicholas A. Planning Armageddon: British Economic Warfare and the First World War. Cambridge, MA and London: Harvard University Press, 2012. 
Latham, A. J. H., and Larry Neal. "The International Market in Rice and Wheat, 18681914." Economic History Review 36, no. 2 (1983): 260-80.

Lehmann, Sibylle H. "The German Elections in the 1870s: Why Germany Turned from Liberalism to Protectionism." Journal of Economic History 70, no. 1 (2010): $146-78$.

Lehmann, Sibylle, and Oliver Volckart. "The Political Economy of Agricultural Protection: Sweden 1887." European Review of Economic History 15, no. 1 (2011): 29-59.

Lewis, Ethan. "Immigration and Production Technology." Annual Review of Economics 5, no. 1 (2013): 165-91.

Lopez, Robert S. "The Trade of Medieval Europe: The South." In The Cambridge Economic History of Europe from the Decline of the Roman Empire: Volume 2: Trade and Industry in the Middle Ages, edited by Cynthia Postan, Edward Miller, and M. M. Postan, 306-401. Cambridge: Cambridge University Press, 1987.

Manacorda, Marco, Alan Manning, and Jonathan Wadsworth. "The Impact of Immigration on the Structure of Wages: Theory and Evidence from Britain." Journal of the European Economic Association 10, no. 1 (2012): 120-51.

Milward, Alan S. The European Rescue of the Nation-State. 2nd edition ed. London: Routledge, 2000.

Mitchener, Kris James, and Se Yan. "Globalization, Trade, and Wages: What Does History Tell Us About China?" International Economic Review 55, no. 1 (2014): 131-68.

Obstfeld, Maurice, and Alan M. Taylor. Global Capital Markets: Integration, Crisis, and Growth. Cambridge, U.K. and New York: Cambridge University Press, 2004.

Offer, Avner. The First World War: An Agrarian Interpretation. Oxford: Clarendon Press, 1989.

O’Rourke, Kevin H. “The European Grain Invasion, 1870-1913.” Journal of Economic History 57, no. 4 (1997): 775-801.

—. "Two Great Trade Collapses: The Interwar Period and Great Recession Compared." IMF Economic Review 66, no. 3 (2018a): 418-39.

—. Une Brève Histoire Du Brexit. Paris: Odile Jacob, 2018b. Updated Englishlanguage version published as A Short History of Brexit: From Brentry to Backstop. London: Penguin, 2019.

O'Rourke, Kevin H., and Alan M. Taylor. "Cross of Euros." Journal of Economic Perspectives 27, no. 3 (2013): 167-92.

O'Rourke, Kevin H., Alan M. Taylor, and Jeffrey G. Williamson. "Factor Price Convergence in the Late Nineteenth Century." International Economic Review 37, no. 3 (1996): 499-530.

O'Rourke, Kevin H., and Jeffrey G. Williamson. "Late Nineteenth-Century AngloAmerican Factor-Price Convergence: Were Heckscher and Ohlin Right?” Journal of Economic History 54, no. 4 (1994): 892-916.

- "Open Economy Forces and Late Nineteenth Century Swedish Catch-Up. A Quantitative Accounting." Scandinavian Economic History Review 43, no. 2 (1995): 171-203.

- Globalization and History: The Evolution of a Nineteenth-Century Atlantic Economy. Cambridge, MA: MIT Press, 1999.

- "When did Globalisation Begin?" European Review of Economic History 6, no. 1 (2002): 23-50. 
_. "Did Vasco Da Gama Matter for European Markets?" Economic History Review 62, no. 3 (2009): 655-84.

O'Rourke, Kevin, Jeffrey G. Williamson, and Timothy J. Hatton. "Mass Migration, Commodity Market Integration and Real Wage Convergence: The Late-NineteenthCentury Atlantic Economy." In Migration and the International Labor Market, 1850-1939, edited by Timothy J. Hatton and Jeffrey G. Williamson, 203-20. London: Routledge, 1994.

Ottaviano, Gianmarco I. P., and Giovanni Peri. "Rethinking the Effect of Immigration on Wages." Journal of the European Economic Association 10, no. 1 (2012): $152-97$.

Pascali, Luigi. "The Wind of Change: Maritime Technology, Trade, and Economic Development." American Economic Review 107, no. 9 (2017): 2821-54.

Powell, Robert. "War as a Commitment Problem." International Organization 60, no. 1 (2006): 169-203.

Rodrik, Dani. "Why Do More Open Economies Have Bigger Governments?" Journal of Political Economy 106, no. 5 (1998): 997-1032.

- "Populism and the Economics of Globalization." NBER Working Paper No. 23559, Cambridge, MA, July 2017.

Rogowski, Ronald. Commerce and Coalitions: How Trade Affects Domestic Political Alignments. Princeton: Princeton University Press, 1989.

Rosenbloom, Joshua L. "Was There a National Labor Market at the End of the Nineteenth Century? New Evidence on Earnings in Manufacturing." Journal of Economic History 56, no. 3 (1996): 626-56.

Rossabi, Morris. "The 'Decline' of the Central Asian Caravan Trade." In The Rise of Merchant Empires: Long Distance Trade in the Early Modern World 1350-1750, edited by James D. Tracy, 351-70. Cambridge: Cambridge University Press, 1990.

Rowe, David M. "The Tragedy of Liberalism: How Globalization Caused the First World War." Security Studies 14, no. 3 (2005): 407-47.

Schonhardt-Bailey, Cheryl. From the Corn Laws to Free Trade: Interests, Ideas, and Institutions in Historical Perspective. Cambridge, MA and London: MIT Press, 2006.

Schroeder, Paul W. The Transformation of European Politics, 1763-1848, Oxford History of Modern Europe. Oxford: Clarendon Press, 1994.

Strange, Susan. "Globaloney?" Review of Globalization in Question, P. Hirst, G. Thompson; The Logic of International Restructuring, W. Ruigrok, R. van Tulder; The Myth of the Global Corporation, P. Doremus, W. Keller, L. Pauly, S. Reich. Review of International Political Economy 5, no. 4 (1998): 704-11.

Tabellini, Marco. "Gifts of the Immigrants, Woes of the Natives: Lessons from the Age of Mass Migration.” Harvard Business School Working Paper No. 19-005, Boston, MA, 2019.

Taylor, Alan M., and Jeffrey G. Williamson. "Convergence in the Age of Mass Migration." European Review of Economic History 1, no. 1 (1997): 27-63.

Temin, Peter. Lessons from the Great Depression. Cambridge, MA: MIT Press, 1989.

Timmer, Ashley S., and Jeffrey G. Williamson. "Immigration Policy Prior to the 1930s: Labor Markets, Policy Interactions, and Globalization Backlash." Population and Development Review 24, no. 4 (1998): 739-71.

Tooze, Adam. The Wages of Destruction: The Making and Breaking of the Nazi Economy. London: Allen Lane, 2006. 
Tooze, Adam, and Ted Fertik. "The World Economy and the Great War." Geschichte und Gesellschaft 40, no. 2 (2014): 214-38.

Ward-Perkins, Bryan. The Fall of Rome and the End of Civilization. Oxford: Oxford University Press, 2005.

Williamson, Jeffrey G. “The Impact of the Corn Laws Just Prior to Repeal.” Explorations in Economic History 27, no. 2 (1990): 123-56.

- "Globalization, Convergence, and History." Journal of Economic History 56, no. 2 (1996): 277-306.

- "Globalization and Inequality, Past and Present." World Bank Research Observer 12, no. 2 (1997): 117-35.

_. "Globalization, Labor Markets and Policy Backlash in the Past." Journal of Economic Perspectives 12, no. 4 (1998): 51-72.

_. "Land, Labor, and Globalization in the Third World, 1870-1940." Journal of Economic History 62, no. 1 (2002): 55-85.

—. "Explaining World Tariffs, 1870-1938: Stolper-Samuelson, Strategic Tariffs, and State Revenues." In Eli Heckscher, International Trade, and Economic History, edited by Ronald Findlay, Rolf G. H. Henriksson, Håkan Lindgren, et al., 199-228. Cambridge, MA: MIT Press, 2006.

- Trade and Poverty: When the Third World Fell Behind. Cambridge, MA: MIT Press, 2011.

Wilson, Andrew, and Alan K. Bowman, eds. Trade, Commerce, and the State in the Roman World. Oxford: Oxford University Press, 2017.

Xie, Bin. "The Effects of Immigration Quotas on Wages, the Great Black Migration, and Industrial Development." IZA Discussion Paper No. 11214, Institute of Labor Economics, Bonn, Germany, December 2017. 